\title{
Regular Population Census and Sustainable National Development in Nigeria; A Cost And Benefit Analysis
}

\author{
Emeh, Ikechukwu Eke \\ Department of Public Administration and Local Government, \\ University of Nigeria \\ Olise, Charles Nnamdi \\ Department of Public Administration and Local Government, \\ University of Nigeria \\ Idam, Macben Otu \\ Department of Public Administration and Local Government, \\ University of Nigeria \\ Nwokolo, Chukwudi Christopher \\ Centre for Entrepreneurship Development Research (CEDR), \\ University of Nigeria
}

Received: May 26, 2020 Accepted: June 29, 2020 Online published: July 27, 2020

doi:10.5296/jpag.v10i3.17441～URL: https://doi.org/10.5296/jpag.v10i3.17441

\begin{abstract}
This paper examined the issues around census population and its impact on sustainable national development by comparing the budgetary cost of conducting regular population census with the developmental cost of not conducting regular population census. Data for the study were generated through a well-structured questionnaire from purposively selected respondents in the ministry of Finance, ministry of Budget \& National Planning and National Population Commission. 300 respondents were enumerated and the data generated was coded and analyzed with STATA with the help of the descriptive statistics which was used to
\end{abstract}


address the objectives of the study with mean cut-off of 2.5 for acceptance or rejection. The result showed (mean $=3.22$ ) which implies that the developmental cost of not conducting regular population census outweighs the budgetary cost of conducting population census regularly. As a result, we recommended that national development planning must be based on up-to-date data generated from regular decennial population census and followed up with the estimations of the National Bureau of Statistics within the intervals.

Keywords: population census, development planning, national development, budgetary cost and developmental cost

\section{Introduction}

Census is an essential source of data for development planning in any country (Okeibunor, 1997). Population census has been defined as an aggregation of all the procedures involved in the collection, compilation and publishing of demographic, economic and social data of all individuals in a country or delineated area of a country at a particular time (Kucypynky, 1980). The expansion of human population across the globe alongside human civilization with its associated societal needs/problems has increased the importance of population. As a result, vital basic information such as age, gender, residential status, place of birth, employment status, educational status, tribe, religion, marital status, etc are generated from population census exercises (Idike and Eme, 2015).

Data generated from this census are required for development planning in areas of budgeting for education, agriculture, health, housing welfare, technology and industrial advancement. It also serves in ascertaining demographic issues created by changes in trends and living conditions, with the aim of developing appropriate population policies; and guesstimating targets for human capital development and utilization that is in sync with the current economic realities (Adamu, 1989). The above stated essence of census is a testimony to the relevance of regular population census to the Federal, state and local governments, as well as the individuals (Omaba 1969). Unfortunately, ascertaining the actual number of people in Nigeria and their demographic characteristics has remained topical to scholars and administrators as well as the international community as regard how these data are generated, its authenticity and reliability (Idike and Eme, 2015).

Indeed, controversy has always surrounded population census in Nigeria, perhaps because of the misgivings and misconceptions associated with it. It is well documented that in some sections of the country, some people do not present themselves to be counted as they fear the essence of the exercise is for tax imposition. In some other sections, some, especially the women are not culturally permitted to be presented for counting due to the culture and/or religion of the people (Ogbuagu, 2004). These issues and others such as non existence or shortage of enumerators with requisite technical knowhow, poor transportation network, lack of access to some hinterlands and communication facilities have fraught census exercise in Nigeria in the past. But the 1991 and 2006 censuses showed an improvement in what used to be the normal in the country. Observers have given credit to the number of capable technical enumerators for this improvement. 
Unfortunately, the current reality is that these improved enumerators (both technically and numerically) have derailed from their initial role of helping in the improvement of population census exercise having been found culpable in falsifying population figures, not minding the implication of such actions on national development. The gross irregularities evidenced in the widespread gap between population estimate for the country and the actual census result by about 30million people in the 1991 population exercise is just one point to their culpability (Brass 1991 cited in Idike and Eme. 2015). Not just that many states challenged the figures allotted to them, they even queried the reliability of the census figure. The case of Lagos state that was allotted a figure shat showed about $30 \%$ decrease to the one they conducted internally is another instance. The implication is that the nation seems to be dependent on estimated figure for developmental planning despite the huge amount of resources expended in population census exercises (Agunlade, 2000).

This trend is a backward step to the days of colonial administration that relied heavily on estimates of the Nigerian population until the first attempt at a nationwide census in 1952-53, upward to the rejected 1962 census that was recounted in 1963; to the 1973, 1991, and 2006 population census. Given that Nigeria had her last census in 2016, it implies that by the virtue of the fact that census is normally done every ten years, Nigeria has thus been overdue for another census exercise since 2016 (Fawehinmi (2018). Regrettably, inadequate financial resources have been cited as reason for rescheduling the exercise for 2018, which did not hold at the instance of lack of fund. But to any discernable mind in Nigeria, the proposed census did not hold not because of lack of fund but because the leadership of the country was enmeshed in the politics of 2019 general elections. This is because, if it were to be for lack of fund, the 2019 election would not have held since it also consumed a huge budget. Beside, the Nigerian government were only required to provide 51 percent of the budget while international donors were to provide the remaining $49 \%$ of the funding (UNFPA 2002).

This position has left some concerned Nigerians wondering if reliable population data needed for developmental planning is expendable, especially giving the developmental challenges confronting the country currently. As a follow up to this assertion, especially based on the concept of optimal targeting under resources or budgetary constraints, the paper seeks to:

$\checkmark$ ascertain the essence of regular population census;

$\checkmark$ examine the budgetary cost of conducting regular population census in Nigeria;

$\checkmark$ find out the impact of the cost of conducting regular population census on national budget; and

$\checkmark$ discover the negative impact of not conducting regular population census on sustainable national development

\section{Review of Relevant Literature and Theoretical Framework}

The review of relevant literature was done thematically.

\section{Population Census; A Conceptual Discourse}

Census, population and census population have attracted a lot of discourse. But it will be 
appropriate to understand the concept extensively. According to Idike and Eme (2015), census refers to the process of retrieving, compiling and publishing demographic, economic and social data pertaining to all persons in a country at a particular time. This means that it is a periodic and deliberate head-count of all residents of a country at a given time, but it is worthwhile to add that the process heralds a systematic approach at obtaining data on members of a particular society or community. Obasanho (2018), while defining census as the exercise that counts the people of a particular area at a specific point in time, also added that it is for a special programme and organizational plan. In terms of scope, she further stated that census is the largest statistical work of a national scale that allows for the obtaining of information about population quantity and characteristics. Such characteristics include the settlement of people within the territory of the country, the population density, composition by gender, age, nationality and socio-economic structure, level of education etc. some scholars have use the term to cover the number of persons and their housing characteristics. This may be the reason insee.fr (2016) defined population census as the counting of the homes and the people living in a particular area in other to ascertain the main characteristics of the people and their houses such as gender, age, activity, professions, characteristics of the households, size and type of housing, modes of transport, daily travel.

In essence, what is expected to in any census exercise is summarized, processed and published information on the size, composition, and location of the population. However, the United Nations (1998) did not only define population census as the total process of collecting, compiling, evaluating, analysing and publishing or otherwise disseminating demographic, economic and social data pertaining, at a specified time, to all persons in a country or in a well delimited part of a country, it went further to define the essential features of censuses as individual enumeration, universality within a defined territory, simultaneity and defined periodicity, which it recommended be taken at least every 10 years (The United Nations, 2008; CES 2010). This 10 years interval is in keeping with the practice in the United States of America and some other countries of the world such as France and even Nigeria. The U.S. Census Bureau succinctly stated that the United States' population statistics come from decennial censuses, which count the entire U.S. population every ten years, along with several other surveys (https://www.census.gov/topics/population.html).

While census has long origin dated back to the 1800 in France performed every 5 years up to 1936 usually on a traditional count, extending to the period between 1946 and 1999 census interval varied from 6 to 9 years. This practice of traditional count has been replaced with annual census survey in 2004. However, towns with resident s not up to 10,000 were to continue with an exhaustive census as in the past but once every 5 years instead of every 8 or 9 years (insee.fr, 2016).

In today's Nigeria, the first census was conducted $\mathrm{f}$ in 1866 specifically for Lagos. The second census was conducted in 1871, but after these census exercises, census became a decennial exercise for Northern and Southern Provinces of Nigeria and by extension the contemporary Nigeria (Idike and Eme 2015) As a decennial exercise, population census has both principles and characteristics listed by the United Nations as: (i) enumeration of individually separately as way as the individuals 'characteristics (ii) the census exercise 
covers every person residing in a defined territory. Within this frame, the housing census include every type of building and living quarters; (iii) each person and each type of building and living quarters is enumerated with respect to a well defined point of time; and (iv) census is taken at regular defined intervals, usually every 10 years (United Nations, 2008).

Obasanho (2018) listed the basic principles of population census as: (1) covering the entire population; (2). Simultaneously conducted across the width and breadth of the country, (3) uses the same program (questionnaire, rules, methods, documentation) across the whole country; (4) done within a very short period of time through direct interviews, filling in questionnaires according to the respondent answers; (5) conducted during the season of the year when the movement of people is the smallest; and (6) every person in the country responds to the same questions.

With the principles and characteristics serving as a guide in conducting population census, data generated guide the federal government in taking decisions on the social policies and infrastructures to be implemented; the urban policies for transport, housing, cultural and sports facilities, school infrastructures and the installation of facilities for young people and senior citizens. The data generated are also useful to the private stakeholders in projecting where to cite businesses (insee.fr, 2016).

Even in the socialist countries, censuses are of enormous importance as data generated from the exercise serve as the foundation for state administration and for planning the development of the national economy and culture. According to measureevaluation.org, in many countries of the world, data from population census are quintessential for the allotment of elected political seats in government. This is because the number of elected officials for each governmental administrative unit is determined by the size of a given locale. In some countries, the allocation of government resources is based on data generated from census exercise. As a result, size of the population determines, in part, the amount of money that is provided by government for development efforts. For planners, data from census exercises provide information on the age and sex distribution, as well as household composition and size, which are vital in determining the needs of different segments of the population and as such influences planning decisions making. This same data also helps to identify segments of the population that require different types of services and provides insights into family formation and housing needs. In the areas of housing, it helps to determine housing needs of the people of a polity. By providing information on the educational skills of the work force and also insights into the labour force of a given locale, census data helps in employment planning. Generally, the information generated via population censuses are used to develop economic development strategies (www.measureevaluation.org).

\section{The History of population Census exercises in Nigeria}

The history of population census exercises in Nigeria is well documented. This may have to do with its importance to national development planning. Therefore, interests are keen on the history of census population in Nigeria perhaps because of the history of the country itself given the fact that the entity called Nigeria today was a conglomerate of different natives with their unique peculiarities. These different natives were however, colonized and administered 
as one entity in 1914 under Lord Lugard. This little background has a lot of influence of the documented history of census population in Nigeria today. According to Ezeah, Iyanda and Nwangwu, (2013), the first documented census in the entity called Nigeria was conducted by the British in 1866. Subsequently there were others censuses in 1871, 1896, 1901, 1911, 1921. These censuses were conducted in the Southern protectorate.

However, in 1952 another census was held. This exercise included the Northern Protectorate with a total population figure of 31.6 million persons (www.Nigeriacensus-history.com). The 1952 census of Nigeria indicated that the Hausa-Fulani had the largest share of the population, and so they dominated the first post-colonial government set up after independence in 1960 . But the result of the census and its aftermath on governance did not go down well with the entire country. Two years after independence, precisely in 1962, another census was conducted with the northerners accounting for only 30 percent of the population (Library of Congress, 1999). The result was rejected because the North had lost its majority share of the country's population even though the north's population went up from 16.5 million in the last census in 1952 to 22.5 million, but it was a paltry increase of $30 \%$, when compared with the $200 \%$ increase in population in some parts of the East and $70 \%$ in general. Again, upward increase of up to $70 \%$ was recorded for the West (Fawehinmi, 2018). A fresh census was conducted the next year (1963).

In the exact of words of Fawehinmi (2018), this time, an additional 8.5 million people were discovered in the north bringing the total to 31 million for the north (a figure higher than the population of every other country in Africa at the time) and 56 million for Nigeria as a whole. Even though this figure was widely thought to be substantially overstated, skewed and biased, it was nonetheless given official recognition and acceptance (http://business.highbeam.com). The official recognition and acceptance given to the result resulted in massive northern dominance in governance and developmental project in the country. The outcome was an accelerated ethnic tension that culminated in the Nigerian civil war that lasted till 1970 (Weeks, 2008).

Even after the war, tension continued trailing the result of the population census that gave massive influence to the northern part of Nigeria. This gave rise to another census in 1973 which was rejected by the government. But in 1991 another census was conducted and 88.5 million people were recorded. This figure was however below the 110 million people that many population experts had projected (Okolo, 1999).

This lends credence to the argument that the 1963 population census figure was inflated. However, the 1991 census result led to a whole lot of accusations and counter accusations about falsification and inflation of figures. Even the reported sex ratio of 101.3 was contested as it was found to defy world standard and expectation (Okeibunor, 1995). To salvage the situated that has lingered more than a decade, another census was conducted in March, 2006 and the result was provisionally given as 140.0 million Nigerians. Though the 140million figure result was a bit higher than the 134 million people projection made by the United Nation, the total population is not the issue per se but its regional (north and south) distribution because of its sensitivity in terms of political and developmental conviviality as 
population census figure is crucial in determining who gets what, where and when in Nigeria. But the census shows a virtually unchanged division (North- 53.3 per cent versus South 46.7 per cent in 1991; 53.6 vs 46.4 in 2006 (Ezeah, et al 2013).

Table i. The history of population census in Nigeria

\begin{tabular}{|l|l|l|}
\hline S/No & Year & Remark \\
\hline 1 & 1886 & Under the British rule prior to amalgamation \\
\hline 2 & 1871 & Under the British rule prior to amalgamation \\
\hline 3 & 1896 & Under the British rule prior to amalgamation \\
\hline 4 & 1901 & Under the British rule prior to amalgamation \\
\hline 5 & 1911 & Under the British rule prior to amalgamation \\
\hline 6 & 1921 & Under the British rule few years after amalgamation \\
\hline 7 & $1952-3$ & Contested \\
\hline 8 & 1962 & Rejected and re-conducted the next year \\
\hline 9 & 1963 & Contested but officially received and used \\
\hline 10 & 1973 & Not accepted by the government \\
\hline 11 & 1991 & Officially accepted by highly contested \\
\hline 12 & 2006 & $\begin{array}{l}\text { Officially endorsed though keenly contested and a little above the } 134 \\
\text { million UN projection }\end{array}$ \\
\hline 13 & 2016 & Projected but did not hold \\
\hline
\end{tabular}

\section{Source: authors' compilation}

\section{The link between Population Census and national Development}

Having established that population census is a method used to generate and accumulate statistical data about a population (Osinaike, Aiyeola \& Alao, 2006), it is vital to assert here that such statistical data is critical to the development of the area in question. This criticality of the vital statistics is the reason it was established that population census is not a haphazard exercise but a process that is systematically organized. Its organized approach led to the establishing of the national population commission by the Federal Government of Nigeria in 1988 with the mandate of conducting a reliable national population census for the country (www.population.gov.ng). The implication is that the commission is by the law mandated to collect, analyze and disseminate population/demographic data in the country, as well as monitoring the country's Population Policy as an instrument for strategic planning and sustainable development (Ezeah, et al, 2013). The above assertion is insightful especially when seen from Sade Balogun's perspective that if we do not generate information on how many people that are living in a place at the particular period of time, a comparative analysis of the socio-cultural, economic, social and demographic changes will be difficult if not impossible, let alone estimating the living standard of the people in order to forecast the perspective of national development and national population growth (Balogun, 2018). This links to Obasanho's (2018) assertion that the results of population censuses are of great importance for current and future planning of changes in the sphere of national economy, the development of the economy, health, culture. Hence, population census appraises the past, 
describes the present accurately and forecast the future (Sherrif, 2018). To be effective in forecasting the future, Obasanho (2018) asserts that the health indicators such as physical development, morbidity, mortality; development of a network of institutions of preventive and curative care, the right number of doctors, beds; for the study of reproduction, fertility indicators, life expectancy, to calculate the perspective of the population, etc are calculated with the help of data from population census as the authorities take management decisions based on this data.

In terms of housing, the information generated by a population and housing census concerning the numbers of people, their distribution, their living conditions and other key data, is critical for development. This is because the data directs policymakers to where to invest (UNFPA nd). Unfortunately, many countries have outdated or inaccurate data about their populations and therefore, without accurate data are unable to address the needs of their population. UNFPA stated that, the unique advantage of the census is that it represents the entire statistical universe, down to the smallest geographical units, of a country or region. Planners need this information for all kinds of development work, including: assessing demographic trends; analysing socio-economic conditions; (Corcos, 2017) designing evidence-based poverty- reduction strategies; monitoring and evaluating the effectiveness of policies; and tracking progress toward national and internationally agreed development goals. In addition to making policymakers aware of population issues, it is also an important tool for identifying forms of social, demographic or economic exclusions, such as inequalities relating to race, ethics and religion as well as disadvantaged groups such as those with disabilities and the poor. An accurate census can empower local communities by providing them with the necessary information to participate in local decision-making and ensuring they are represented. As governments assumed responsibility for schooling and welfare, large government research departments made extensive use of census data (https://www.insee.fr/en/metadonnees/definition/c1486).

\section{Challenges of Census Population}

Census exercises are faced with many challenges. According to Skinner, (2018), in few decades ago, population census globally has been fraught with issues such as cost pressures on the budget, concerns about intrusiveness, privacy and response burden, reduced cooperation, difficulties in accessing secure apartments and enumerating unsafe areas, more complex living arrangements, and timeliness concerns. The reoccurring political, social and economic interferences with census exercise in Nigeria over the years are some basic issues and challenges (Library of Congress, 1999).

These interfacing of political, social and economic factors in the census processes have continued to not only linger but gather momentum over the years. This is the reason for the controversies associated with any and every single census held in Nigeria. These controversies are politically motivated and waged along economic, social, religion and ethnic lines with total disregard for the detrimental effects these controversies will have on the development of the country. The reason for this is the public perception that higher population figures is a political weapon in a heterogeneous society like Nigeria. In other 
words, the higher the population figures the more government amenities, the demand for more seats in the parliament, more local governments and states to be created from a particular tribe or region. This inherent socio-ethnic consciousness and the battle for political dominance among Nigerian geopolitical regions have continued to defeat the main aim of national population census as an instrument for strategic planning and sustainable development (Library of Congress, 1999). These struggles do not mind the fact that lack of accurate census figures may have contributed to Nigeria's policy summersault and under development, hence regrettable that in this 21 st century, under the $4^{\text {th }}$ Republic, Nigeria still does not have reliable census data. Sadly, when a nation does not know the proportion and the total number of its citizens, its planning process is likely to be distorted.

According to soapboxie (2016), high illiteracy rate; inadequate infrastructural facilities in certain areas; traditional and religious beliefs; corruption; insufficient census experts; insufficient and ineffective census educational campaign; and poor demographic maps are core challenges of population census exercise in Nigeria. These eight problems may be correct but the issues of high illiteracy and insufficient census experts, Nigeria is expected to have overcome by now. But Ikande's (2018) study on the problems of population census in Nigeria still captured them. According to the study, the main obstacles of conducting a census in Nigeria are ethnic and religious disputes; distribution of natural resources and wealth; falsification of the results and corruption; cost of the census; high level of illiteracy; obsolete infrastructure in some areas; insufficient qualification of census specialists; low efficiency and poor quality of educational campaigns; and unreliable demographic maps. Even though it seems that the 9 factors outlined as the main problems bedevilling census in Nigeria, Sherrif identified one core challenge called politicization of census process and the result. According to Sherrif (2018), one of the fundamental challenges facing population census in Nigeria is politicization of the census. Take for instance; when Tafawa Balewa emerged the Prime Minister in 1962, a new census of the Nigerian population was conducted. But the results were rejected and considered incorrect; a year after, a new one took place in 1963. This time the results were accepted by the central government, despite the fact that it was rejected by the eastern and western regions. Indeed, there is really too much at stake to ignore the growing threat to a successful census because being undercounted in any census exercise deprives an already vulnerable community fair representation and public resources (Eric, 2017).

According to Odimegwu (2013), there is no doubt that faulty population figures drastically affect planning and, invariably, development. This is largely at the root of Nigeria's poor human development index and overall backwardness in most parameters of national transformation. At the heart of the unreliable censuses over the years are the twin devils called ethnicity and religion. Unfortunately for Nigeria in particular and Africa in general, these two indicators have remained the main problems of population census in Nigeria because of the struggle for supremacy on both grounds by the three major ethnic groups in the country and their religion. The clamour for supremacy by the three combative ethnic behemoths in the country must be confronted if the country is to advance in citizen data collation. 
Unfortunately, the government has failed to harness the importance of population census for planning, progress and development because of the role of ethnicity and religion in today's politics (Diamond, 1988). Nigerian national population census has been a victim of intense elite contestation for political and economic power, accusation of regional bias and favouritism, popular distrust, resistance and widespread suspicion of the census results. This is a proven fact hence, as Oyedele, (2013) asserted that the National Population Commission (NPC) had admitted that it does not have accurate figures on Nigeria's population because the various estimates that have been presented by the commission in the past have been mired in controversy. Indeed, Census is of great value and population data is sine qua non to sustainable development (Ezeah, et al 2013) and as such unless the census challenges are comprehensively managed and grey areas resolved, Nigeria will continue to wallow in the milieu of socioeconomic quagmire arising from blind and unrealizable projections (Odimegwu, 2013).

\section{The theory of cost-benefit analysis and the conduct of regular population census}

This study adopted the theory of cost-benefit analysis (CBA) as it theoretical frame of analysis. The theory is the principal analytical framework that evaluates public expenditure decisions. The cost-benefit analysis provides a consistent procedure for evaluating decisions in terms of their consequences; thus, offering clear guidelines for the evaluation of government decisions in such varied fields as tax, trade, or incomes policies; the provision of public goods; the distribution of rationed commodities; or the licensing of private investment and conducting regular population census (Drèze and Stern, 1987). Indeed, data gathered from the national population census allows for critical evidence-based decision making through all levels of government, regarding planning, monitoring and evaluation over a period. These data offer demographic, population and economic baseline information that ensures equity in distribution of government services and informs the allocation of government resources.

Unfortunately, the imperatives of census data notwithstanding, census data have not been sufficiently exploited as key data source for development planning due to logistics and financial challenges especially in the developing nations such as Nigeria. Thus, it becomes imperative to do a cost-benefit analysis of conducting regular population census in a country estimated to be over 200 million persons endowed with crude oil and many other natural resources yet globally referred to as the poverty capital of the world.

\section{Data and Methods}

The survey research design was chosen for this study. This led to the use of a well-structured simple questionnaire to elicit information from the purposively chosen respondents in the Ministry of Finance, Ministry of Budget \& National Planning and National Population Commission Abuja offices. The choice of these enumeration centres were based on their relative knowledge of the budgetary cost and benefits of conducting regular census in Nigeria over irregular conduct of population census. The questionnaire used for this study was structured in two (2) sections. The first section (Section A) presented the personal information of the respondents while the second section (Section B) addressed the main issue 
of this study. A total of 300 randomly selected respondents were enumerated with 100 respondents from each enumeration centre. The elicited information from the respondents was coded with STATA, while descriptive statistics was used in analyzing the coded data. However, simple percentages and frequencies were used to analyze the personal information of the respondents while mean and standard deviation was used to address the objective of this study. The choice of the mean was based on the likert scale nature of the items. The decision for the acceptance or rejection of the mean was based on the standard 2.5 cut-off point for a 4 point likert scaled instrument.

\section{Result}

Table ii: Frequencies and Percentages for Personal information of sampled respondents

\begin{tabular}{|c|c|c|}
\hline Personal information type & Frequency & Percentages \\
\hline \multicolumn{3}{|l|}{ Sex } \\
\hline Male & 176 & 58.67 \\
\hline Female & 124 & 41.33 \\
\hline \multicolumn{3}{|l|}{ Education } \\
\hline Secondary education & 8 & 2.67 \\
\hline Tertiary education & 188 & 62.67 \\
\hline Postgraduate education & 104 & 34.67 \\
\hline \multicolumn{3}{|l|}{ Marital Status } \\
\hline Single & 55 & 18.33 \\
\hline Married & 226 & 75.33 \\
\hline Divorced/Separated & 13 & 4.33 \\
\hline Widowed & 6 & 2.00 \\
\hline \multicolumn{3}{|l|}{ Age } \\
\hline 30 years and below & 2 & 0.67 \\
\hline 31 to 40 years & 226 & 48.67 \\
\hline 41 to 50 years & 13 & 31.33 \\
\hline Above 50 years & 6 & 19.33 \\
\hline \multicolumn{3}{|l|}{ Work Designation } \\
\hline Budget \& National Planning & 100 & 33.33 \\
\hline Finance & 100 & 33.33 \\
\hline National Population Commission & 100 & 33.33 \\
\hline \multicolumn{3}{|l|}{ Length of Service } \\
\hline 5 years and below & 52 & 17.33 \\
\hline 6 to 10 years & 118 & 39.33 \\
\hline 11 to 15 years & 80 & 26.67 \\
\hline 16 to 20 years & 50 & 16.67 \\
\hline
\end{tabular}

Source: Field Survey, 2019

The result on table 1 deals with the personal information of the sampled respondents. From the table, $58.67 \%$ of the respondents were male while the remaining $41.33 \%$ were female. 


\section{Mll Macrothink}

Journal of Public Administration and Governance

ISSN 2161-7104

2020, Vol. 10, No. 3

This showed that most of the sampled respondents were male. On the highest completed education of the respondents, $2.67 \%, 62.67 \%$ and $34.67 \%$ of the respondents had secondary education, tertiary education and postgraduate education as their highest completed education respectively. This result indicates that most of the sampled respondents as expected have completed tertiary education. More so, the result on table 1 showed that $18.33 \%, 75.33 \%$, $4.33 \%$ and $2 \%$ of the sampled respondents were single, married, divorced/separated and widowed respectively. This indicated that most of the sampled respondents were married.

Furthermore, the result for the age of the sampled respondents showed that $0.67 \%$ and $48.67 \%$ were 30 years and below and 31 to 40 years respectively. On the other hand, $31.33 \%$ and $19.33 \%$ of the respondents were aged 41 to 50 years and above 50 years respectively. The result here indicates that most of the respondents were above 30 years and probably have worked in their place of work for a long time. Then again, the result for the work designation of the sampled respondent indicated that an equal proportion of the respondents came from each of the enumeration centres. What this means is that 100 respondents each were gotten from ministries Budget \& National Planning and Finance and the National Population Commission. Going further, $17.33 \%, 39.33 \%$ and $26.67 \%$ of the respondents have worked for 5 years and below, 6 to 10 years and 11 to 15 years respectively in their current place of work. The remaining $16.67 \%$ of the respondents have worked for 16 to 20 years in their present place of work. This shows that majority of the respondents have worked for more than 5 years in their current place of work. The result here has implication for this study as majority of the respondents have stayed long enough in their place of work to know whether its most beneficial for the country to engage in regular census or not, considering the cost of engaging in the census.

Table iii: Mean, Standard Deviation (SD) and Decision for Cost and benefits of regular population census on sustainable development

\begin{tabular}{lcccc}
\hline \multicolumn{1}{c}{ Item Statement } & Mean & SD & Decision \\
\hline $\begin{array}{l}\text { Regular census is useful for proper sustainable national } \\
\text { development through national development planning }\end{array}$ & 3.10 & 0.79 & Accepted \\
$\begin{array}{l}\text { The Budgetary Cost of Conducting Population Census is very high } \\
\text { The cost of regular population census will not adversely affect the } \\
\text { national budget. }\end{array}$ & 3.47 & 0.73 & Accepted \\
$\begin{array}{l}\text { Without regular national population census, it will be difficult to } \\
\text { achieve sustainable development. }\end{array}$ & 3.14 & 0.71 & Accepted \\
\hline Cluster summary & $\mathbf{3 . 2 2}$ & $\mathbf{0 . 5 4}$ & Accepted \\
\hline
\end{tabular}

Source: Field Survey, 2019

Table 2 presented the result for the cost and benefits of regular population census on sustainable development of Nigeria. From the result, all the items had means of 3.00 and above. This showed that they were above the minimum mean for acceptance of 2.5 which necessitated the 'accepted' in decision column. In specific term, the respondents accepted with a mean of 3.10 that regular population census is useful for proper national development through development planning. Also, the respondents accepted with mean of 3.26 that the 
budgetary cost of conducting population census is high, but will not negatively impact on the national budget as the respondents accepted with a mean 3.47 that the cost of regular population census will not adversely affect the national budget. Lastly, with a mean of 3.14, the respondents accepted that without regular national population census, it will be difficult to achieve sustainable development. Therefore, the benefit of conducting regular population census is higher than the cost of conducting the exercise.

\section{Discussions}

\section{The Essence of Regular Population Census is unequivocal in Nigeria}

The importance of conducting regular population census in Nigeria, and indeed, elsewhere in the world is firmly rooted in the famous quote of the renowned management thinker - Peter Ducker "you cannot manage what you cannot measure". Hence, information about the size of the population, its geographical distribution and the social, demographic and economic characteristics of a people are generated from population census. But the potency and uniqueness of data generated through census compared with most alternative sources of statistical information reside in its complete geographic coverage and the continuity and comparability of statistics from census to census (UNFPA, 2002). In contemporary times, data from the population census are used to measure population of rural and urban settlements, to ascertain the number of voters in a particular constituency, and the availability of health and education facilities, to know the percentage of ethnicity or religious populations etc. It is also helpful in improving socio-economic conditions by providing employment opportunities in accordance with availability of manpower. According to Junejo (2017), data from census can be beneficial in improving law and order situations as better calculations lead to better distribution of facilities. With better facilities chances of people being involved in crime can be reduced to a greater extent.

Unlike the days of medieval Europe and Greece when census was primarily conducted for the purpose of determining the population of men fit for war or tax collection, today, census represents a "complete health report" of the national socio-economic body that generates detailed check-ups to diagnosis real socio-economic suffering even at grassroots levels. Thus it provides opportunities to the country's administrators to cure these sufferings by making stringent efforts at engendering good governance. In this scenario, when the government is not even aware the actual population growth rates it would be difficult for it to run state machinery for the welfare of common man and lay claim to good governance (Junejo, 2017).

According to Masiteng, (2011), while census data is essential to the government, it is also used within a variety of other domains such as international planning, government planning, economic insight, informing business and individual uses. He furthered explained that at the international level, the census data allows international organizations to plot a country's progression and define its current standing. This type of information impacts on funding requirements, as well as investment. It is also used for monitoring developmental programmes such as the Millennium Development Goals (MDGs) and its current version "Sustainable Development Goals" (SDGs) which is a global action plan aimed at providing numerical benchmarks for tackling poverty around the world. 
From the national government point of view, data gathered from the national census allows for critical evidence-based decision making through all levels of government, regarding planning, monitoring and evaluation over a period. The census data offers demographic, population and economic baseline information. It ensures equity in distribution of government services and informs the allocation of government resources. It is therefore fundamental in shaping policy outcomes in a number of areas, such as assessing programmes on gender equity, the ageing population and infant, children and productive groups or planning, monitoring and evaluating housing, health and welfare programmes. Data from census can also be used as a baseline for other essential statistical information like electricity supply and demand or for delineating electoral districts. When the information gathered from census impacts directly on government policy and direction, education and service provision, it in turn affects every person living in the country (Masiteng, 2011).

The most important thing about census in the African context is that data therefrom gives a crystal view of the dynamics of poverty. This critical point may have spurred Mike Schussler of the economics.co.za to assert that the national census is the dashboard of the economy, like an airplane's dashboard, it tells you how many passengers are on board and where the plane is, so you can decide at what height you must fly, what speed, and what you must do to stop stalling.

This is because various rates and figures such as the unemployment rate, labour absorption rate, labour force participation rate and the ratio of the labour force to the labour supply are calculated from census data. More so, census statistics are the benchmarks for statistical compilation or as a sampling frame for official statistics surveys which inform public policy at far shorter time intervals than the five-year or ten-year interval of national censuses because they provide further insights into demographic and socio-economic trends. Census data assist businesses in planning and strategy for product development as well as forecasting of demand for products and services. Beyond the direct benefit that individuals gain from the census data being used to inform government planning and decision making, people can use it in other ways, to be better informed about buying a home, job relocation or starting a small business (Masiteng, 2011).

\section{The budgetary cost of conducting regular population census in Nigeria}

According to Ikande (2018), carrying out a national population census is quite an expensive project which the authorities always find ways to avoid. This is why the process usually gets postponed often because governments hardly want to bear the huge financial costs. Even, when it holds, the procedure does not get carried out efficiently and as regular as it should. Whereas literature is silent on the costs of population census exercise in this area currently known as Nigeria, especially those of 1886, 1871, 1896, 1901, 1911, and 1921, Fawehinmi, (2018) has however asserted that the $1962 / 63$ population census was held at a cost of $\$ 6.2$ million (about $\$ 50$ million today) .

The 2006 census cost the federal government some \$266milion (about \#53 billion now) even though half of the money was provided by the European Union and other multilaterial international donors (Adegbamigbe, 2015). The National Population Commission proposed a budget of \#283 billion to conduct a population census in 2006. However, in another 
development two years later, the Director General of the National Population Commission, Ghali Bello, said that the National population census will hold in 2018 if necessary logistics are provided and that the proposed 2018 census will cost an estimate of \#272 billion. This estimated N272 billion, the Federal Government was expected to provide 51 per cent while the international donor community will provide remaining 49 per cent (Agency Report, 2017). This support notwithstanding, the proposed census did not hold perhaps because the budget for the census was huge and the shrinking public sector budgets.

Accordingly, a study by Leete (2001) found that cutbacks in funding for international development assistance (which use to be the major source of funding censuses in the past) have heightened the problems. He then, recommended adequate and timely financial and technical supports to developing countries that lack sufficient technical and financial resources

\section{The impact of the cost of conducting regular national population census on national budget}

National population censuses are the largest, most elaborate and costliest data-collection activity that statistical offices undertake in a country, and costs are still rising. In Nigeria, a national population census accounts for around 5 per cent of the budget of the country for the year in question. Take for instance the 2006 population census that cost some N53 billion. The budget of the year was N1.9trillion. This was about 5\% of the year's budget. In my opinion, this should not impact on the national budget considering the percentage. Considering again, the projected N283 billion for 2016 population census and the N6.06 trillion; N7.29 trillion; N8.612 trillion; and N8.83 trillion budget for 2016, 2017, 2018 and 2019 respectively, the proposed amount is about 5 percent of the national budget. The table below compares the budgets of the years under review with the budgets of censuses and elections that held within the time under study.

Table v. Cost of population census, elections and national budgets from 1962/3-2019

\begin{tabular}{|llll|}
\hline Date & $\begin{array}{l}\text { National budget } \\
(\mathbf{N})\end{array}$ & $\begin{array}{l}\text { Census cost } \\
(\mathbf{N})\end{array}$ & $\begin{array}{l}\text { Election cost } \\
(\mathbf{N})\end{array}$ \\
\hline $\mathbf{1 9 6 3}$ & $£ 3 \mathrm{~m}$ & 50 million & \\
\hline $\mathbf{1 9 9 9}$ & $299 \mathrm{bn}$ & & N1. 5 Billion \\
\hline $\mathbf{2 0 0 3}$ & 1.45tn & & 29 Billion \\
\hline $\mathbf{2 0 0 6}$ & 1.88 billion & 53 Billion & \\
\hline $\mathbf{2 0 0 7}$ & 2.39 trillion & & 45 Billion \\
\hline $\mathbf{2 0 1 1}$ & 4.7 trillion & & 111 Billion \\
\hline $\mathbf{2 0 1 5}$ & 4.5 trillion & & \\
\hline $\mathbf{2 0 1 6}$ & 6.06trilion & 272 billion & \\
\hline $\mathbf{2 0 1 9}$ & 8.83 trillion & & 242.45 Billion \\
\hline
\end{tabular}

Source: Compiled by the authors.

The above table showed the budgetary cost of population census in 2006 is a bit higher than 
the cost of election in 2007. But since the international community and donor agencies always give funding assistance of about 45 percent, it means that the government did not spend above N28 Billion which is lesser than the N45 billion cost of 2007 general election. More so, whereas, a regular population census is expected to be decennial, election holds every four years and funds are always available for it. Therefore, the cost of population census does not impact negatively on the annual budget of the state. However, let the government pay attention to the one factor that contributes immensely to the increase in census costs in developing countries (like Nigeria) -high population growth. In many of these countries, annual population growth exceeds 2 per cent per annum, implying an increase in population size of at least one third over a normal 10-year census period (Leete 2001).

Even in industrialized countries, per capita census costs are rising, despite the use of mail-out and mail-back questionnaires, sophisticated computer data-processing technology and relatively low population growth. For example, the United States population census in 2000 is estimated to have cost $\$ 4.5$ billion, or $\$ 16$ per head, compared with a figure of around $\$ 10$ per head in 1990 (Kent, 2001). Rising costs of censuses, coupled with a lack of detailed data about census costs is the core challenges of conducting regular population census in Nigeria. This lack of detailed and available data about census cost is not peculiar to census cost, even the outcome of the census exercise have been said to be politicized and weaponized (Fawehinmi, 2018) so much that governments do no longer see the need to commit huge part of the national annual budget into a futile exercise. But for the high premium on census data, the United Nations has emphasized the need for countries to keep account of the cost of each census activity. Again, and more fundamental, censuses need to be more cost-effective even though the exercise will remain costly despite the use of modern relatively low-cost computer technology. There is, therefore a fine balance between keeping census costs to a minimum and preserving the unique advantages of a census. Whether the cost of censuses impact greatly on the national budgets or not, the exercise has to be institutionalized. It has to have its cycle embedded hence UNFPA has found that, unless sufficient resources are available at each stage of the census, the quality of the entire census can be jeopardized.

\section{The negative impact of not conducting regular population census on sustainable national development}

The impact of not having regular population census in any country has been feared among international donor agencies hence ((Leete, 2001) their avowed stand to support or counter-fund census exercises in the less-developing countries with sufficient resources to conduct regular population census. Even though census is a very capital-intensive activity, the major concern of donor communities is the outcome of regular census that equips the government of those countries with up to date and accurate data of her citizens in order to aid proper developmental planning. This planning when optimally done will help the government to be effective and efficient in allocation of resources to sectors that really need intervention. In this regard, regular population census has implication for trade, manufacturing and security because it provides the biometrics of every Nigerian that guides good planning. (Vanguard 17/04/2018). 
However, without regular population census that gives evidenced-based population data, the planning for development and developmental programmes are adversely affected. This is so because the lack of data and the unreliability of existing ones make waste of resources unavoidable. This is because scarce resources are allocated to areas where they are not direly needed while the areas in dire need of such funds are starved of developmental attention and funding. In the Nigerian case, this scenario has gravely impinged on policy-making and planning across a broad spectrum of sectors and even in the assessment of progress towards national and international development goals. This is without prejudice to the fact that developing countries are at differing levels of statistical capability that has produced data gaps even with censuses. However, these data gaps are what current and regular censuses are to forestall. The essence is to close the gap or policy distortions that unreliable and the lack of basic population data will have on serious policy making and resource allocations

\section{Conclusion}

Population census is indisputably, a unique source of data for developmental planning purposes in countries around the world especially in developing counties like Nigeria. The African countries have conducted population census sparsely due to funding challenges. Nigeria is a clear example. Using the N272 billion projected budget for the proposed 2016 census that was postponed to 2018 and eventually did not hold, one can conclude that whereas Nigeria appreciates the values of population census that are crucial for national and sub national policies and plans for development framework, but the funding challenges have negatively impacted on the conducting of the population exercise as well as the outcomes of the exercise. Fortunately, the international communities and donor agencies have been rendering wonderful financial assistances to ensure steady and effective conduct of population census in Nigeria. Therefore, the government should strive to conduct regular population census ones in every ten years to enable her generate reliable data about her population with which to plan for her developmental needs given the importance and potency of these data and the funding supports readily available by international donor agencies.

However, as an addendum to escaping the crisis of funding the population census exercise for onward stability, there is a need for researches into census costs and operational mechanisms to reduce costs and maximize the timely dissemination and use of valid census data; and securing the necessary funding within countries and from the donor community.

\section{References}

Abdallah, N. M. (Aug 3, 2018). 2019 elections set to be Nigeria's most expensive. https://www.dailytrust.com.ng/2019-elections-set-to-be-nigeria-s-most-expensive-263938.ht $\mathrm{ml}$

Adamu, S. O. (1989). Population and Planning in Nigeria', in Tekema, T. and Atanda, J. A., (Eds), Nigeria Since Independence: The 25years government and Public policy, Nigeria, Ibadan: Heinneman Publications.

Adegbamigbe, A. (Aug 11 2015). News Analysis: At N283billion, Nigeria's census costlier than 
https://www.thenewsnigeria.com.ng/2015/08/11/news-analysis-at-n283billion-nigerias-censu s-costlier-than-indias-or-chinas/

Agency Report (April 9, 2017). Nigeria’s planned 2018 census to cost N272 billion - Official. https://www.premiumtimesng.com/news/headlines/228350-nigerias-planned-2018-census-cos t-n272-billion-official.html

Balogun, S. (2018). History of Population Census in Nigeria. https://www.legit.ng/1208578-history-population-census-nigeria.html

Corcos, N. (2017). Excavations and Watching Brief at the Corner of Wade Street and Little Anne Street, St Jude's, Bristol, 2014". Internet Archaeology, (45). https://doi.org/10.11141/ia.45.3

Diamond, L. (1988). Class, ethnicity, and democracy in Nigeria: The failure of the first republic. Syracuse University Press. https://doi.org/10.1007/978-1-349-08080-9

Drèze, J., \& Stern, N. (1987). The theory of cost-benefit analysis. In Handbook of public economics (Vol. 2, pp. 909-989). Elsevier. https://doi.org/10.1016/S1573-4420(87)80009-5

Eric, A. L. (August 30, 2017). Problems threaten the accuracy of 2020 US Census. https://usa.inquirer.net/6257/problems-threaten-accuracy-2020-us-census?utm_expid=.XqNw Tug2W6nwDVUSgFJXed.1\&utm_expid=.XqNwTug2W6nwDVUSgFJXed.1

Ezeah, P., Iyanda, C., \& Nwangwu, C. (2013). Challenges of National Population Census and Sustainable Development in Nigeria: A Theoretical Exposition. IOSR Journal Of Humanities And Social Science (IOSR-JHSS), 18(1), 50-56. https://doi.org/10.9790/0837-1815056

Fawehinmi, F. (March 6, 2018). The story of how Nigeria's census figures became weaponized. https://qz.com/africa/1221472/the-story-of-how-nigerias-census-figures-became-weaponized/

Idike, A., \& Eme, O. I. (2015). Census politics in Nigeria: an examination of 2006 population census. Journal of Policy and Development studies, 289(1851), 1-26.

Ikande, M. (2018). Problems of Population Census In Nigeria. https://www.legit.ng/1133808-problems-population-census-nigeria.html

insee.fr (13/10/2016). Population census.

https://www.insee.fr/en/metadonnees/definition/c1486

Junejo, I. (January 24, 2017). Census: Benefits and need. https://nation.com.pk/24-Jan-2017/census-benefits-and-need

Kucynpynky, R. (1948). Encyclopedia of Social Sciences, Macgill: New York.

Kwache, E. (April, 17, 2009). Population Census In Nigeria, The Case Of Michika Adamawa State. http://www.ngex.com/news/public/article.php?ArticleID=916

Leete, R. (2001). Population and Housing Censuses; A Funding Crisis? Symposium on Global Review of 2000 Round of Population and Housing Censuses: Mid-Decade Assessment and 
Future Prospects. Statistics Division, Department of Economic and Social Affairs, United Nations Secretariat New York, 7-10 August 2001

Masiteng, K. (07 Oct 2011). Census benefits more than just government https://mg.co.za/article/2011-10-07-census-benefits-more-than-just-government

Measureevaluation.org (nd). Lesson 4: Use of Census and Related Population Information. https://www.measureevaluation.org/resources/training/online-courses-and-resources/non-certi ficate-courses-and-mini-tutorials/population-analysis-for-planners/lesson-4

Obasanho, S. (2018). What is population census? https://www.legit.ng/1093709-what-population-census.html

Odimegwu, F. (2013). Nigerian Census Challenge: Our Report. The Sun $11^{\text {th }}$ August 2013, P.1

Ogbuagu, S. C. (2004). 'Fundamentals of Population Census in Nigeria: A paper presented at the awareness seminar', Umuahia, P. 5-6.

Ogunlade, M. U. (2000). Population and Society, New York: Oxford University press.

Okeibunor, L. C. (1997). Great Issues in Government and Politics, Enugu.

Omaba, R. N. (1969). The role of government in population census project in Africa, New York.

Oyedele, D. (2013). NPC: We lack accurate figures on Nigeria Population. Thisday Newspaper, April 19 p. 1 Retrieved from online on 15/01/19.

Sherif (April 26, 2018). History Of Population Census In Nigeria. https://peakng.com/history-of-population-census-in-nigeria/

Skinner, C. (2018). Issues and Challenges in Census Taking. Annual Review of Statistics and Its Application, (5), 49-63. https://doi.org/10.1146/annurev-statistics-041715-033713

Soapboxie. (November 2, 2016). Problems of census https://soapboxie.com/social-issues/7-Problems-of-Census

UNECE (nd) CES 2010 Census Recommendations. Unece.org. Retrieved 2013-11-19.

UNFPA - United Nations Population Fund (nd). Census . UNFPA.org. Retrieved 2016-07-20.

UNFPA (2002). Population and Housing Census: Strategies for reducing cost. Number 4. New York, NY

United Nations (1998). Principles and Recommendations for Population and Housing Censuses, Revision 1, New York

United Nations (2008). Principles and Recommendations for Population and Housing Censuses. Statistical Papers: Series M No. 67/Rev.2. p8. ISBN 978-92-1-161505-0.

US Census Bureau (nd). Population https://www.census.gov/topics/population.html 


\section{Macrothink}

Journal of Public Administration and Governance ISSN 2161-7104

Weeks, J. R. (2008). Population: An Introduction to Concepts and Issues tenth edition. London: Wadsworth Ltd.

Wordpress (nd). History and Development of the Census in England and Wales. theforgottenfamily.wordpress.org. Retrieved 2019-01-10.

\section{Copyright Disclaimer}

Copyright for this article is retained by the author(s), with first publication rights granted to the journal.

This is an open-access article distributed under the terms and conditions of the Creative Commons Attribution license (http://creativecommons.org/licenses/by/4.0/). 